\title{
Arnoldia kuesii, a new juvenile fernlike plant from the Lower Permian of New Mexico
}

\author{
William D. Tidwell
}

Sidney Ash

Follow this and additional works at: https://scholarsarchive.byu.edu/facpub

Part of the Geology Commons

\section{Original Publication Citation}

Arnoldia kuesii, a new juvenile fernlike plant from the Lower Permian of New Mexico. Sidney R. Ash and William D. Tidwell Botanical Gazette (Chicago) (June 1986), 147(2):236-242

\section{BYU ScholarsArchive Citation}

Tidwell, William D. and Ash, Sidney, "Arnoldia kuesii, a new juvenile fernlike plant from the Lower Permian of New Mexico" (1986). Faculty Publications. 1449.

https://scholarsarchive.byu.edu/facpub/1449

This Peer-Reviewed Article is brought to you for free and open access by BYU ScholarsArchive. It has been accepted for inclusion in Faculty Publications by an authorized administrator of BYU ScholarsArchive. For more information, please contact ellen_amatangelo@byu.edu. 


\title{
ARNOLDIA KUESII, A NEW JUVENILE FERNLIKE PLANT FROM THE LOWER PERMIAN OF NEW MEXICO
}

\author{
SIDNEY ASH AND WILLIAM D. TIDWELL \\ Department of Geology, Weber State College, Ogden, Utah 84408; and Department of Botany and Range Science. \\ Brigham Young University, Provo, Utah 84602
}

\begin{abstract}
A nearly complete juvenile fernlike plant is described here from Lower Permian rocks of New Mexico. The fossil consists of a horizontal rhizome with roots, a short thick upright aerial branch, and a tuft of dimorphic leaves. It is assigned to Arnoldia kuesii gen. et sp. $\mathrm{n}$. and appears to be the first juvenile fernlike plant known from the Upper Paleozoic. Abundant palynomorphs and other plant fossils associated with the fossil indicate that it is Early Permian in age.
\end{abstract}

\section{Introduction}

Typically, fossil vascular plants are represented in the geologic record by disassociated organs such as leaves, stems, roots, and reproductive structures that usually cannot be related to one another with total confidence. Only rarely has an entire or nearly entire fossil plant been found in which several organs actually are connected. As a result, most reconstructions of fossil plants are hypothetical, the organs having been assembled on the basis of association, similarity of structure, and/or analogy with modern plants. Two relatively entire fossil juvenile plants that have been described are Eddya sullivanensis from the Upper Devonian of New York (BECK 1967) and Aethophyllum stipulare from the Middle Triassic of France (Grauvogel-STAMM 1978). Here we describe the third such rare find from the Lower Permian of New Mexico. The fossil includes a rhizome with roots, an aerial branch, and leaves. This fortuitous association is noteworthy because it probably represents a young herbaceous plant and thus appears to be the first reported juvenile fernlike plant from Upper Paleozoic rocks. The fact that it is nonarborescent is also significant because of the apparent bias against the preservation of the remains of small herbaceous plants in the fossil record (ScHeIHING 1980). Although the leaves on the fossil resemble previously described taxa, such as Sphenopteris and Eusphenopteris, it is assigned to Arnoldia kuesii gen. et sp. n. because of its dimorphism.

\section{Material and methods}

The fossil (fig. 1) is preserved as a compression in soft tan shale (figs. 2, 3). The part (fig. 2) and most of the counterpart (fig. 3) are present, and morphological details are relatively clear. Portions of the fossil were uncovered to clarify the attach-

Manuscript received March 1985; revised manuscript received November 1985.

Address for correspondence and reprints: WILLIAM D. TIDwELL, Department of Botany and Range Science, Brigham Young University, Provo, Utah 84602. ment of the leaves to the aerial branch (fig. 5). Unfortunately, the cuticle on the fossil was not preserved. The fossil was studied and photographed when both dry and immersed in kerosene. A sample of the matrix was examined by Dr. A. TRAVERSE, Pennsylvania State University, who found that it contained abundant, well-preserved palynomorphs. The specimen is deposited in the collections of New Mexico Museum of Natural History, Albuquerque (NMMNH), and has been assigned no. D31-P1056.

\section{SOURCE OF MATERIAL}

LOCALITY.-The fossil was collected from Carrizo Arroyo near the north end of Sierra Lucero in central New Mexico ca. $45 \mathrm{~km}$ southwest of Albuquerque and $30 \mathrm{~km}$ west of Los Lunas. No further geographical data are presented to avoid plundering of the site before the scientific work is completed. However, locality data may be obtained from the authors by professional scientists.

STRATIGRAPHY.- The specimen came from the Red Tanks Member of the Madera Formation of Late Pennsylvanian and Early Permian age. In the Sierra Lucero area the Red Tanks Member is the uppermost unit in the Madera and is overlaid by the Abo Formation of Early Permian age (KeLLEY and Wood 1946). KUES and KiETZKe (1976) restudied the stratigraphy of the Red Tanks Member in Carrizo Arroyo and reported that the member in this area is ca. $150 \mathrm{~m}$ thick and consists of a sequence of mainly dark red siltstone, sandstone, and shale overlaid by a series of gray, thin-bedded nodular limestone and shale. The fossil was obtained from a 1.5 -m-thick bed of tan shale ca. $70 \mathrm{~m}$ above the base of the Red Tanks Member and in the dark red siltstone sequence.

AgE.-The Red Tanks Member of the Madera Formation was thought to be Late Pennsylvanian (Kottlowski 1960; Kues and Kietzke 1976) or possibly Early Permian (BATES et al. 1947; READ and WOOD 1947) in age. A preliminary evaluation of the plant megafossils in the deposit indicates that the flora is of Early Permian age (ASH and TID- 


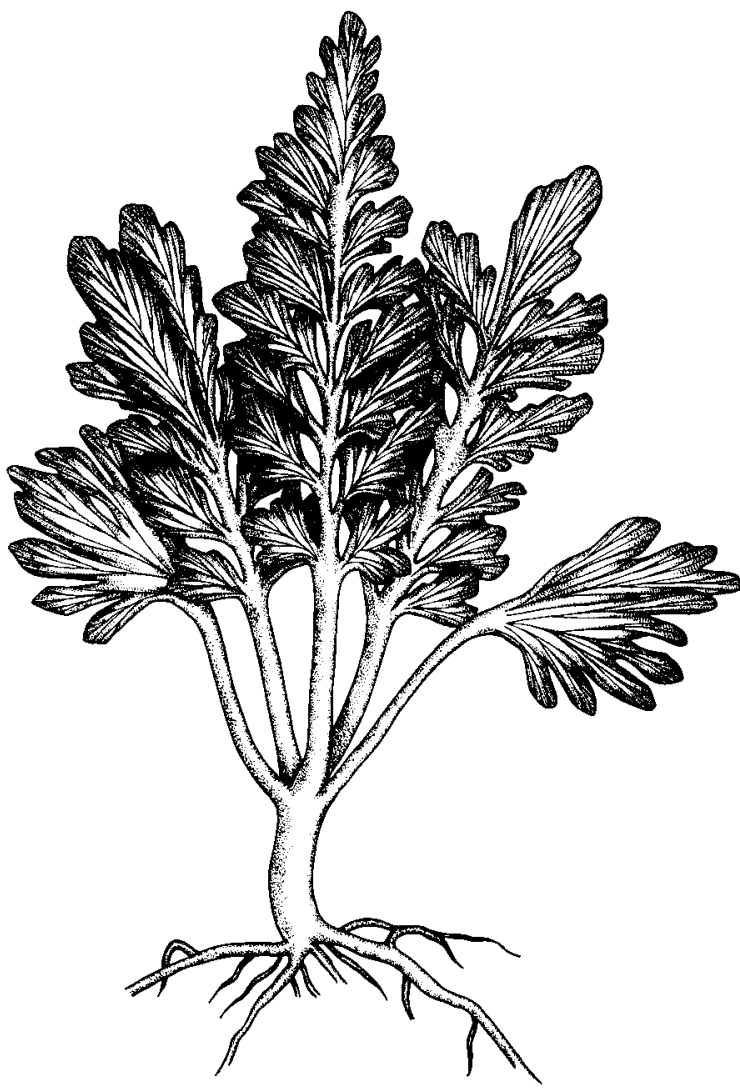

FIG. 1.-Reconstruction of the Arnoldia kuesii gen. et sp. n. plant. Compare with figs, 2, 3. Ca. $\times 1$.

WELL 1982). TRAVERSE (personal communication, 1983) stated that the associated palynoflora is clearly near the Pennsylvanian-Permian boundary in age, as shown by the dominance of Potoneisporites plus the presence of rare striate pollen grains (two specimens seen). TRAVERSE stated that the rest of the assemblage is in keeping with this conclusion. He also suggests that the presence of even a few specimens of Striatoabeites sp. argues perhaps for earliest Permian rather than late Stephanian (latest Pennsylvanian). Clendenning (1975) found a similar palynoflora in the Dunkard Group of West Virginia and vicinity. BARss et al. (1979), however, considered the Potoneisporites zone to be latest Stephanian, although ARCHANGELSKY and TAIGO (1980) put this zone in the earliest Permian of Gondwanaland.

AssoCIATED FOSSILS. - A large undescribed flora and fauna occur in the Red Tanks member in Carrizo Arroyo in association with the fossil described here. The entire association was reviewed by KuES and KIETZKE (1976), who noted that the invertebrates that occurred at the same stratigraphic level include a large assemblage of eurypterids, unidentified brachiopods, smooth-shelled ostracods, and insects. These were thought to represent a brackish water assemblage. A very diverse near-shore-ma- rine to marine fauna occurred in strata ca. $6 \mathrm{~m}$ above this level. According to KUES and KIETZKE (1976), the fauna includes many brachiopods such as Derbyia, Neochonetes, Juresania, Linoproductus, Composita, and Neospirifer and a variety of productoids. Other fossils include several types of pelecypods, ornate ostracods, crinoids, echinoids, and ophiuroids. Detailed discussions of a new genus and species of insects (KUKalova-PECK and PECK 1976) and of a new species of eurypterids (KUES and KIETZKE 1981) from the sequence have appeared.

Tidwell and Ash (1980) and Ash and Tidwell (1982) recognized one or more species of the following taxa: Asterophyllites, Neuropteris, Odontopteris, Sphenopteris (see fig. 4), Taeniopteris, Cordaites, and Cardiocarpus and various conifers in a large collection from the locality. Also present was a callipterid form and possibly Phasmatocycas.

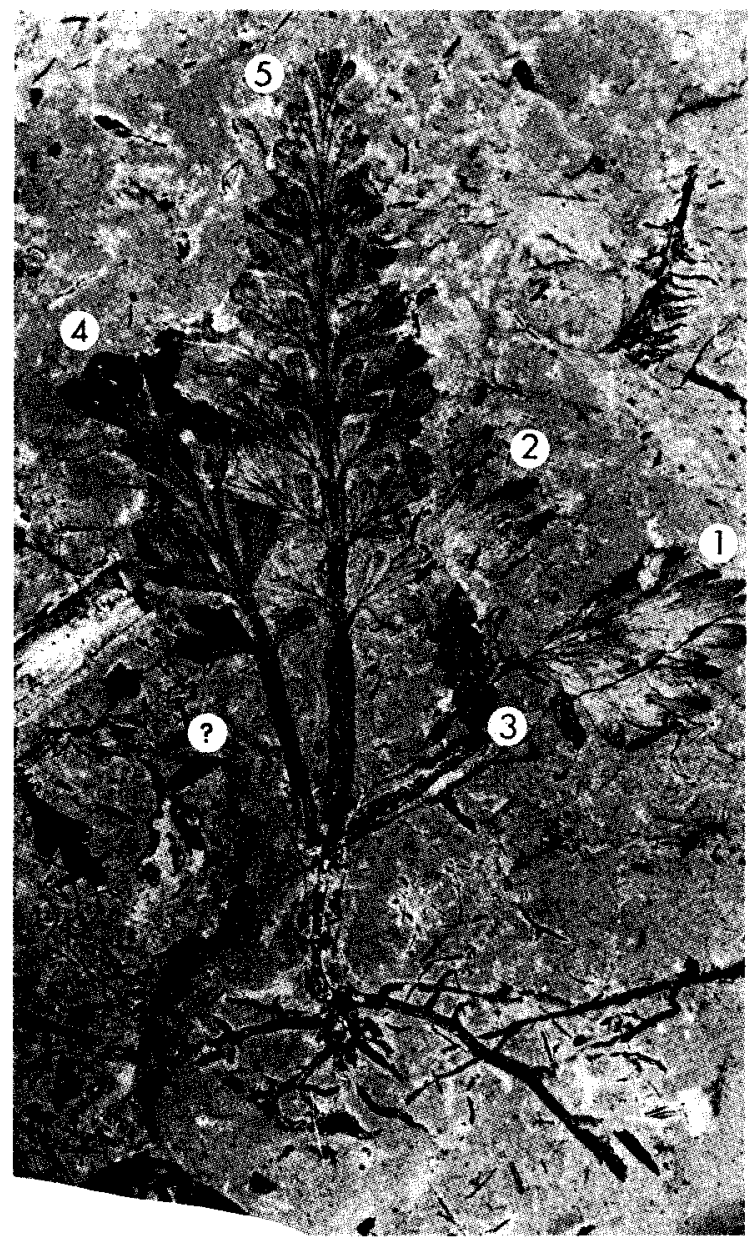

FIG. 2.-Arnoldia kuesii gen. et sp. n. Holotype, NMMNH D31-P1056. Compare with figs. 1, 5. The leaves are numbered from youngest (no. 1) to oldest (no. 5). The question mark shows the remains of a possible young leaf. Red Tanks Member of the Madera Formation. Ca. $\times 1.5$. 

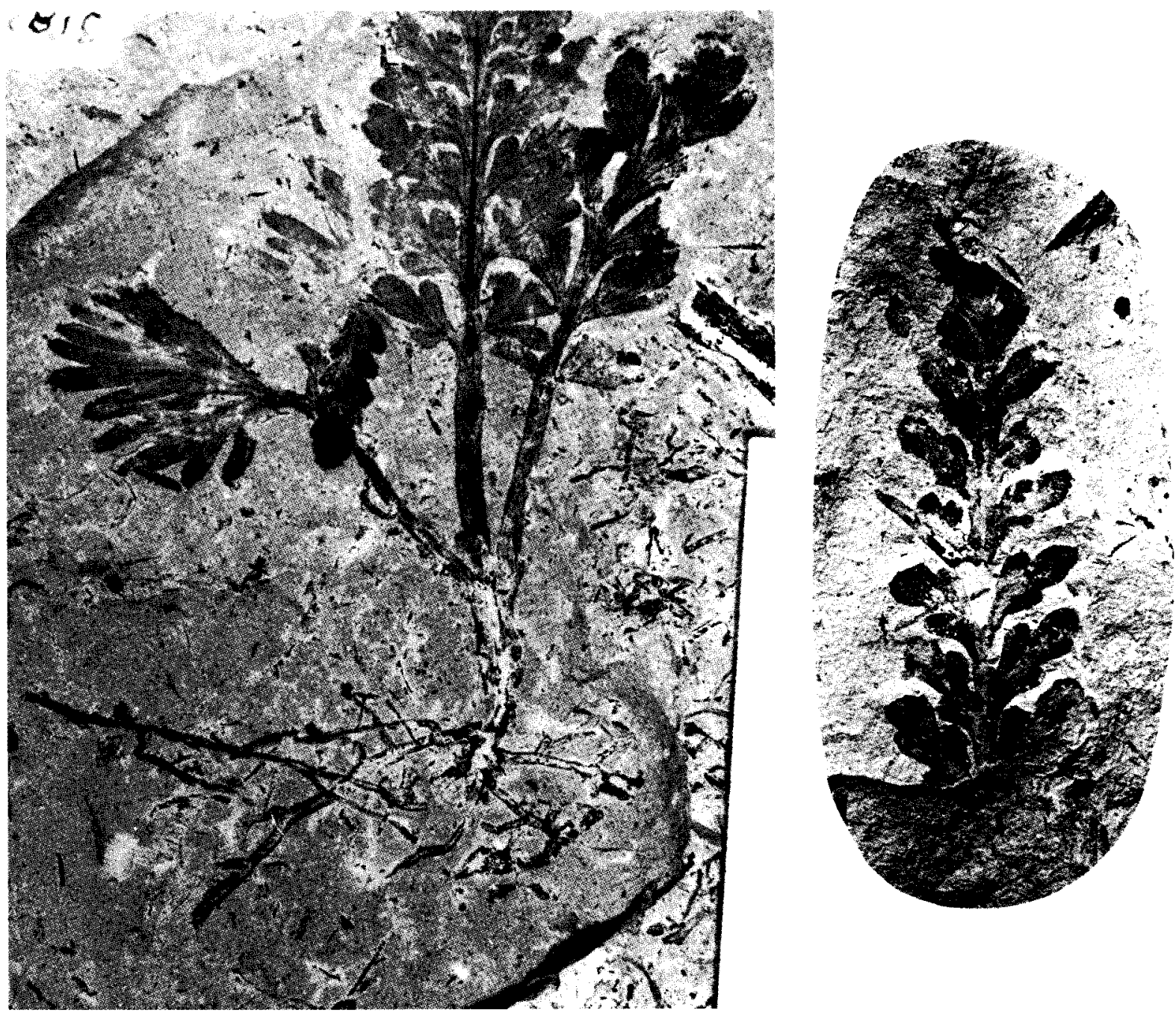

FIGS. 3, 4-Both $\times 1.5$. Fig. 3 (left), Arnoldia kuesii gen. et sp. n. Holotype, NMMNH D31-P1056. Counterpart. Compare with fig. 2. Red Tanks Member of the Madera Formation. Fig. 4 (right), Example of a typical Sphenopteris pinna in the Red Tanks Member of the Madera Formation.

TRAVERSE (written communication 1983) reported that the sample submitted to him contained a large, well-preserved palynoflora and that the most conspicuous forms in the sample were very large monosaccate pollen with a variable central body, usually appressed to one side of the grains and often displaying a monosulcate furrow. Most of the specimens are probably referable to Potoneisporites grandis Tschudy and Kosanke (1966). Other, less abundant monosaccates can be assigned to Nuskoisporites and to Florinites. Bisaccate forms are also common, especially Limitisporites sp. and Alisporites sp. Less common bisaccates are Sulcatisporites sp., Vesicaspora sp., and Pityosporites $\mathrm{sp}$. One specimen of Striatoabeites $\mathrm{sp}$. and one of Vittatina sp. were seen.

In addition, the sample contained an abundant, unidentified, inaperturate rugoreticulate form that may be a conifer-like pollen grain and is probably a new genus. Trilete spores were present but were overshadowed by monosaccates and bisaccates. The trilete spores included Vestispora fenestrata (Kosanke and Brokaw) Wilson and Venkatachala, Osmundacidites sp., and a form apparently identical with SHAFFER's (1964) unpublished genus, "spore genus $f$," from the Permian of Kansas.

\section{Description}

The fossil consists of a horizontal root-bearing structure and a stout vertical branch that bears a tuft of five finely divided, sterile, dimorphic leaves at its apex. The organs are unquestionably attached to each other. For purposes of description, we assume that the understructure is a fragment of a creeping rhizome with roots and not simply a root system.

\section{RHIZOME}

The rhizome is a fairly straight structure that appears to be branched. It is ca. $1 \mathrm{~mm}$ in diameter 
(as compressed) and bears isolated roots at regular intervals except below the leaf, where a concentration of several roots occurs. The roots are ca. $0.5 \mathrm{~mm}$ in diameter (as compressed) at the bases and taper slightly. Their maximum length is ca. 1 $\mathrm{cm}$. The rhizome and roots are represented by a broad $(1 \mathrm{~mm})$ strand of dark, structureless carbonaceous material assumed to represent the vascular tissue, which is bordered (surrounded?) by a narrow $(0.1 \mathrm{~mm})$ zone of light material, presumably constituting the remains of the cortex.

\section{AERIAL BRANCH}

The aerial branch curves upward abruptly from the top of the rhizome and extends ca. $15 \mathrm{~mm}$ above that organ. It is straight above the basal curve and is ca. $4 \mathrm{~mm}$ wide. The branch has a black structureless strand (?the remains of the vascular tissue) ca. $1 \mathrm{~mm}$ wide and a border zone of light-colored material (?the cortical remains). Both zones are continuous with those of the rhizome.

\section{LEAVES}

The leaves arise from the apex of the aerial branch, and each has a smooth naked petiole ca. $1.5-2.0 \mathrm{~mm}$ wide and $1.7-2.0 \mathrm{~cm}$ long. Two types of leaves occur on this plant and, for purposes of this report, are referred to as type 1 and type 2 .

TYPE 1 LEAVES. - Type 1 leaves are assumed to represent the juvenile stage. They have broad, flabellate laminae that are more or less cuneate in shape (leaves $1-3$ on figs. 2, 5). Each leaf consists of three broad, palmate pinnules (ca. $1.5 \mathrm{~cm}$ long, 1 $\mathrm{cm}$ wide) and long, narrow lobes (ca. $2 \mathrm{~mm}$ wide, $6 \mathrm{~mm}$ long) separated by deep, narrow indentations. The venation consists of a midvein that alternately supplies each lobe with a lateral vein that in turn divides, producing three to four veinlets per lobe. Typically the veins end in the apical region of lobes.

TYPE 2 LEAVES. - Type 2 leaves (leaves 4,5 on figs. 2,5 ) are assumed to represent the adult stage. The laminae are linear lanceolate (ca. $6 \mathrm{~cm}$ wide, $8 \mathrm{~cm}$ long) as a whole with acute apices and slightly contracted base, and are divided into pinnately arranged pinnules that are stalked and lobed. Typically, they are opposite to subopposite and generally overlap slightly. The pinnules vary in form and size according to their position on the rachis. Those at the base are ca. $1 \mathrm{~cm}$ long and $0.5 \mathrm{~cm}$ broad and show four lateral, slightly spreading rounded-cuneate lobes and a simple terminal lobe. Further up the rachis the pinnules are triangular in general outline and usually show one to two pairs of rounded-cuneate lobes united to each other by a narrow wing and a rounded terminal lobe. Pinnules higher on the rachis may have one to two lateral, rounded lobes that are not deeply incised. While the upper pinnules may be trilobate, those near the

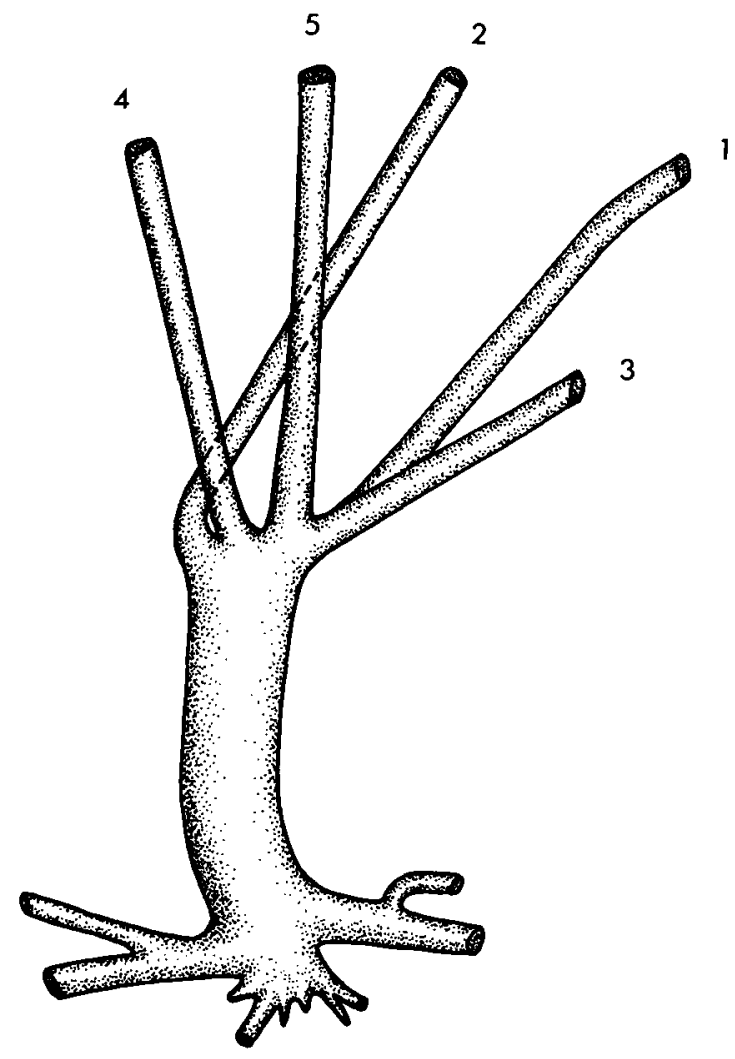

FIG. 5.-Diagram showing the branching of Arnoldia kuesii gen. et sp. n. Drawn from the part (before and after excavation) and the counterpart of the holotype. Numbered as in fig. 2. NMMNH D31-P1056.

pinna apex are entire. The apical pinnule is ca. 5 $\mathrm{mm}$ long and $2 \mathrm{~mm}$ wide. In the lower compound pinnules, the midvein arises acutely from the rachis and passes up the center of the pinnule. A lateral vein is given off alternately into each lobe where it divides into three veinlets, each extending to the pinnule margins. The lowest lateral vein originates on the basiscopic side of the main vein. Venation is sparse in the pinnules, with a concentration of ca. $20-30$ veinlets $/ \mathrm{cm}$ at the lobe margins.

\section{Other fossil juvenile vascular plants}

The other two juvenile vascular plants mentioned above are fairly complete. Unfortunately, it is also uncertain what adult plant they represent, although some suggestions have been made. The Upper Devonian plant Eddya sullivanensis includes a root system attached to a slender stem, which bears helically arranged flabelliform leaves. Unlike the fossil described here, E. sullivanensis is structurally preserved. It has been suggested that this fossil represents a juvenile Archaeopteris (BECK 1967). Aethophyllum stipulare (Brongniart) emend. Grauvogel-Stamm from the Middle Triassic of France is even more complete as it consists of the root system, the stem, the leaves, and male and female reproductive organs in addition to the seeds 
and pollen. Grauvogel-Stamm (1978) suggested that the fossil could be a juvenile Cordaites.

\section{Systematic descriptions}

\section{DIVISION-UNCERTAIN \\ Genus-ARnOldia gen N. ASH AND Tidwell}

DiAGNOSIs. - Plant small, rhizomatous with aerial branch, leaves flabellate and/or pinnate, forming apical tuft on branch. Pinnules of pinnate leaf lobed, stalked, opposite to subopposite. Pinnules of flabellate leaf elongated, palmately arranged.

ETYMOLOGY.- The name honors the American paleobotanist CHESTER A. ARNOLD, who made many contributions to Paleozoic paleobotany.

GENERITYPE. - Arnoldia kuesii sp. n. Ash and Tidwell.

\section{SPECIES-ARNOLDIA KUESII SP. N.}

ASH AND TidWEll (FIGS. 1-3, 5).

DIAGNOSIS. - Sterile part of plant consisting of rhizome, upright aerial branch, and tuft of leaves. Rhizome thick, creeping, bearing small roots. Aerial branch turning upward from top of rhizome, thick, short, smooth, top dividing abruptly into several leaves. Leaves dimorphic, forming basketlike tuft at top of branch, lamina substance thin, veins inconspicuous, petioles short (ca. $2-3 \mathrm{~cm}$ ), smooth. In one type of pinna (juvenile?) lamina flabellate, broadly cuneate in outline; in other type, lamina linear lanceolate. Lamina in first type of pinna divided into several palmate pinnules. Pinnules ca. $1.5 \mathrm{~cm}$ long and $1 \mathrm{~cm}$ wide, divided into several long narrow lobes separated by deep narrow sinuses; midrib straight; lateral veins alternate, one entering each lobe where it forks two to three times; resulting veinlets continuing to apical region of lobe, where they end at the margin. Lamina in second type of pinna divided into pinnately arranged lobed pinnules. Apex of pinna acute, base narrowing slightly. Pinnules 5-10 mm long, 2-5 $\mathrm{mm}$ wide, lobes cuneate with rounded apices, midrib nearly straight, lateral veins alternate, one entering each lobe, forking once or twice dichotomously, resulting veinlets ending in pinnule margin.

HOLOTYPE. - NMMNH D31-P1056.

ETYMOLOGY.- The fossil is named to honor Dr. BARRY KUES of the University of New Mexico who invited us to work on the Red Tanks flora.

LOCALITY.-Carrizo Arroyo, central New Mexico.

Formation.- - Red Tanks Member of the Madera Formation.

AgE._Early Permian.

Discussion.-Arnoldia kuesii gen. et sp. $\mathrm{n}$. seems to be either a young upright fern or seed fern. The aerial branch of the plant appears to terminate with the formation of the leaves. Probably the young plant started by growing only one leaf, as often occurs in extant ferns where one leaf develops initially and the remaining leaves, composing the "basket-like tuft," develop as the plant matures. Such a leaf progression is evident in A. kuesii.

The flabellate leaf (no. 1) at the base of the tuft is an example of a type 1 leaf. It probably is the youngest leaf of the plant and differs from the more mature leaves above it just as juvenile leaves commonly differ from mature leaves in extant plants. The next-youngest leaf (no. 2), also a type 1 leaf, is similar to the first except that it is more dissected and the lobes are longer and more separated. The lamina of the next-youngest leaf (no. 3) is not preserved, but the leaf probably was intermediate in shape between the flabellate form of the younger leaves and the more pinnate form of the older leaf (no. 4).

Leaf no. 4 is opposite the youngest leaf and is an example of the type 2 leaf. It is pinnate, but the pinnules are not as highly dissected as the oldest leaf, and the terminal pinnule is still disproportionately large. The oldest leaf (no. 5) is the middle leaf on this specimen and is also a type 2 leaf. In it the pinnules are approaching what may have been the shape and size of the adult pinnules. The adult fronds, however, may have been multipinnate or even have had a forked rachis, but this cannot be observed on the fossil. The remains of a type 1 leaf occur below leaf 4 (question mark in figs. 2,5 ), but its relationship to the other leaves is unknown, so it is not listed in the sequence given above.

Some ferns such as the lady fern (Athyrium filixfoemina [L.] Roth) and the hard fern (Blechnum spicant [L.] Roth) have a root system and an upright stem (BOwER 1923). In these ferns, numerous large leaves are grouped closely around an apical bud and form a basket-like tuft attached directly to an abbreviated, massive stem called a stock. Although the fossil described here shows a tuft of foliage at the apex of the branch, no apical bud was observed at its tip. The apical bud in A. kuesii, however, may have been so small that it did not produce any large or clearly recognizable structure in the compression.

The creeping rhizome of the fossil strongly contrasts with the upright branch. In extant ferns, the rhizome results from an elongation of the internodes with a consequent greater or lesser isolation of the leaves. For instance, some species of Dryopteris have a creeping habit with long internodes and the leaves are isolated at a distance from each other, as in the specimen of $A$. kuesii (BOWER 1923; BELL and TOMLINSON 1980). Thus, it is likely that the fossil species had long internodes. The roots of $A$. kuesii appear to arise from the top of the rhizome, but this may represent only a quirk of preservation or the way the fossil is oriented in the rock. The roots, however, do arise at specific intervals, in- 
dicating that they arise adventitiously from nodes, which is additional evidence that the understructure is a rhizome.

Preliminary evaluation of the lithology, sedimentary structures, and fossils in the strata containing the plant described here indicates (KUES and KIETZKE 1976) that the sequence represents "a series of ponds or enclosed lagoons on a deltaic plain that were surrounded by dense vegetation. ...." This plant presumably lived along the bank of one of these ponds, was washed out of the bank with the rhizome and root system preserved nearly intact, and was then deposited in the pond where it was almost immediately buried.

COMPARISONS. - No species appears to be similar to the fossil described here because of the dimorphism of its leaves, although individual pinnae are very close to certain species of the genera Eusphenopteris and Sphenopteris. In general outline, e.g., some of the type 2 (mature?) pinnules resemble species placed in Eusphenopteris by VAN AMEROM (1975), particularly E. obtusiloba, E. neuropteroides, and E. aldrichii. However, these species are smaller, and the pinnules are rounder than the cuneate pinnules of $A$. kuesii. Furthermore, the sinus between the lobes of these Eusphenopteris species are more nearly round, more distinct, and more distant than those in the specimen from New Mexico.

The type 2 pinnules on $A$. kuesii are also similar to those of Eusphenopteris sauveurii, but the pinnules of $E$. sauveurii are alternate and smaller, with lobes that are more incised and restricted at their bases. Also, the pinnules and lobes are more rounded, more distant, and more spreading and have more acute apices than in A. kuesii. Finally, the pinnule attachment is decurrent in $A$. kuesii and contracted in E. sauveurii.

The venation of Sphenopteris biturica, S. biturica densipennata, S. fayoli, S. kidstoni, and Prynadaeopteris tunguscana, all from the Stephanian (Late Pennsylvanian) or Permian of Europe, is similar to that in the new species. However, frond size, pinnule shape, and lobe shape of these species differ considerably from that of $A$. kuessi. Also, the apices of these European species are more sharply pointed. In S. biturica and S. kidstoni there is only one lateral veinlet per lobe (two to four per lobe in A. kuesii).

The shape of the type 2 pinnules of $A$. kuesii and typical pinnules of Sphenopteris germanica is similar. The two species differ in the multipinnate aspect of the fronds of $S$. germanica. In addition, the pinnules are closer together and sometimes overlap in $A$. kuesii, whereas they are more distant in $S$. germanica.

Typical Sphenopteris leaves in the Red Tanks flora differ from $A$. kuesii by being multipinnate and having thicker lamina. The pinnules of these fossils are also larger and their apices more rounded than those of $S$. kuesii (fig. 4). Although the possibility exists that $A$. kuesii is actually a juvenile stage of one of the types of isolated (and more mature?) fronds of Sphenopteris in the Red Tanks flora, this cannot be proved, and because the differences, especially the dimorphic leaves, indicate a separate taxon, the fossil plant is here referred to a new genus and species. The similarities of the fossil to Sphenopteris indicate that it may be closely related to that genus.

\section{Acknowledgments}

We are grateful to Dr. BARRY KUES, Department of Geology, University of New Mexico, for inviting us to work on the fossil described in this paper. In addition, we thank NAOMI HEBBERT, Brigham Young University, for her aid with the fern reconstruction, and Dr. Alfred Traverse, Pennsylvania State University, who studied the palynomorphs associated with the fossil. We also thank Dr. R. M. WAGNER, University of Sheffield; Dr. H. W. PFEFFERKORN, University of Heidelberg; Dr. J. K. RigBY, Brigham Young University; and Dr. G. Rothwell, Ohio University, for examining an early draft of this report and giving us their constructive criticisms.

\section{LITERATURE CITED}

ARChANGelsky, S., and M. M. TAIGo. 1980. La palinologia y el problema del limite Carbonico-Permico en el Gondwana Sudamericano. Pages 221-229 in Actas II Congreso Argentino de Paleontologia y Biostratigrafia y I Congreso Latinoamericana de Paleontologia. Buenes Aires, 1978.

Ash, S., and W. D. Trdwell. 1982. Notes on the Upper Paleozoic plants of central New Mexico. New Mexico Geol. Soc. Guidebk., 33d Field Conf., Albuquerque County 2:245248.

Barss, M. S., J. P. Bujak, and G. L. Williams. 1979. Palynological zonation and correlation of sixty-seven wells, eastern Canada. Geol. Surv. Can. Paper 78-24. 118 pp.

Bates, R. L., R. H. Wilpolt, A. J. MacAlpin, and G. Vorbes. 1947. Geology of the Grand Quivira quadrangle, New Mexico. New Mexico School of Mines, State Bur. Mines Mineral Res. Bull. 26. 52 pp.
Beck, C. B. 1967. Eddya sullivanensis, gen. et sp. nov., a plant of gymnospermic morphology from the Upper Devonian of New York. Palaeontographica, pt. B, 121:1-22.

BeLl, A. D., and P. B. TOMLINSON. 1980. Adaptive architecture in rhizomatous plants. Bot. J. Linn. Soc. 80:125-160.

Bower, F. O. 1923. The ferns (Filicales). Vol. 1. Cambridge University Press, Cambridge. 359 pp.

Clendenning, J. A. 1975. Palynological evidence for a Pennsylvanian age assignment of the Dunkard Group in the Appalachian Basin. Pages 195-221 in J. A. BArLow, ed. Pt. 1: Proc. 1st I. C. White Memorial Symp. "The Age of the Dunkard," West Virginia Geol. Econ. Surv.

Grauvogel-Stamm, L. 1978. La flore du Grès a Voltzia (Buntsandstein supérieur) des Vosges du Nord (France): morphologie, anatomie, interprétations phylogénique et paléogéographique. Sci. Géol. Mem. 50. 225 pp. 
Kelley, V. C., and G. H. Wood, JR. 1946. Lucero Uplift, Valenicia, Socorro and Bernalillo Counties, New Mexico. U.S. Geol. Surv. Oil Gas Inv. Prelim. Map no. 47.

KotTlowski, F. E. 1960. Summary of Pennsylvanian sections in southwestern New Mexico and southeastern Arizona. New Mexico Bur. Mines Mineral Res. Bull. 66. 187 pp.

Kues, B. S., and K. KIETZKE. 1976. Paleontology and stratigraphy of the Red Tanks Member, Madera Formation (Pennsylvanian) near Lucero Mesa, New Mexico. Pages 102-108 in New Mexico Geol. Soc. Sp. Pub. 6.

. 1981. A large assemblage of a new eurypterid from the Red Tanks Member, Madera Formation (Late Pennsylvanian-Early Permian) of New Mexico. J. Paleontol. 55:709-730.

Kukalova-PECK, J., and S. B. PECK, 1976. Adult and immature Calvertiellidae (Insecta:Palaeodictyoptera) from the Upper Paleozoic of New Mexico and Czechoslovakia. Psyche 83:79-93.

READ, C. B., and G. H. WOOD. 1947. Distribution and cor- relation of Pennsylvanian rocks in Late Paleozoic sedimentary basins of northern New Mexico. J. Geol. 55:221-236.

SCHEIHING, M. H. 1980. Reduction of wind velocity by the forest canopy and the rarity of non-arborescent plants in the Upper Carboniferous fossil record. Argumenta Palaeobot. 6:133-138

SHAFFER, B. L. 1964. Stratigraphic and paleoecologic significance of plant microfossils in Permian evaporites of Kansas Soc. Econ. Paleontol. Mineralog. Spec. Pub. 11:97-115.

TiDWHLL. W. D.. and S. R. AsH. 1980. Preliminary report on a flora in the Red Tanks Member of the Madera Formation. central New Mexico (abs.). Geol. Soc. Am. Abstracts with Programs 12:305.

Tschudy, R. H., and R. M. Kosanke. 1966. Early Permian vesiculate pollen from Texas, U.S.A. Palaeobotanist 15 (Pts. 1, 2):59-71

VAN AMEROM, H. W. J. 1975. Die Eusphenopteridischen Pteridophyllen. Mededelingen Rijks Geol. Dienst, Ser. CIII-1-No. 7. 208 pp. 